\title{
Issues of Sufficiency of Potential Oil Resources to Maintain Current Oil Production
}

\author{
Shamil M. Valitov ${ }^{1}$, Aydar M. Tufetulov ${ }^{1} \&$ Amur F. Yartiev ${ }^{2}$ \\ ${ }^{1}$ Institute of Economics and Finance, Kazan Federal University, Kazan, Russia \\ 2 TatNIPIneft Tatar Oil Research and Design Institute of OAO TATNEFT, Bugulma, Russia \\ Correspondence: Aydar M. Tufetulov, Institute of Economics and Finance, Kazan (Volga Region) Federal \\ University, Russia. 4, Butlerov st., 420012 Kazan, Russia. Tel: 743-2911-369; 7-987-296-02-92. E-mail: \\ ajdar-t@yandex.ru
}

Received: August 9, 2014 Accepted: September 10, 2014 Online Published: November 14, 2014

doi:10.5539/ass.v10n23p36

URL: http://dx.doi.org/10.5539/ass.v10n23p36

\begin{abstract}
The authors discuss the problem of sufficiency of potential oil resources to meet the energy demands of global economomy, as well as medium-term oil production trends in Russia. According to available estimates and forecasts, oil will dominate global energy needs to 2025. In the coming decades global oil demand will continue to grow to reach 5.96 billion tonnes in 2020, according to analysts' forecasts. Plans for economic development of Russia include further development of production and export capabilities and enhancing Russia's status as an important world energy power. This ambitious goal is underpinned by a strong raw materials base and a developed industrial potential. As projected by "2030 Development Strategy", by the end of the current decade, annual oil production will be raised to 520 million tonnes. Actually, the "2030 Development Strategy" objectives will be achieved at the expense of traditional oil producing regions with the yet high hydrocarbon potential. In today's globalizing world, the advanced countries aim their efforts at building energy-efficient societies, which cannot be done without changing mindsets, development of game-changing technologies, and creating new social institutions. Resource efficiency is seen as an integral part of Russia's sustainable development.
\end{abstract}

Keywords: energy resources, fields, hydrocarbon reserves, investments, expenses, oil production, sufficiency of hydrocarbon reserves

\section{Introduction}

Energy is a key element of any process in current civilizations and an essential condition of the mankind daily living activities. Energy security of a country and availability of a developed energy infrastructure are basic arguments used in taking serious economic decisions. Development of energy industry has become a guarantee for world stability and progress; sustainable, consistent supply of energy sources is critical for global economic growth and increased quality of life of millions of people throughout the world.

Even though power economy is rapidly developing presenting challenging and complex issues to be addressed, non-renewable hydrocarbons still continue to dominate global energy needs.

It is known that energy once used cannot be reused and in such a closed circuit as the Earth the entropy is steadily increasing, so even the increasing energy prices will not turn energy resources deficiency into overabundance (Yartiev, 2012).

Almost after fifty years, oil has revealed the best and the worst in our civilization. It has become a blessing and a burden. Energy is the backbone of any industrial society. Out of all energy sources oil is the most important and the most problematic one because of its central role, due to the strategic nature, geographical distribution, recurring crises in its supply, inevitable and irresistible temptation to grab it for nothing. It will be great if we reach the end of this century without trying to challenge oil supremacy by political, technical, economic or environmental crises, partly predictable, partly unpredictable. We can not expect less from the century, on the formation of which oil has had such a profound impact. Its story has become a panorama of triumphs, tragic and costly mistakes. Oil helped to achieve mastery over the physical world. It provides our lives and, literally, through the agricultural chemicals and transportation, gives us our daily bread. It also stirs world wars for political and economic dominance. A lot of blood was spilled in the name of oil (Daniel Yergin). 
Causes of stock market crashes can be reduced to a few basic theses: firstly, irrational logic periodically prevails the financial markets; secondly, this irrationality also has its own laws; thirdly, a "lender of last resort" is required for the financial markets to weather the crisis successfully; it lends money at a difficult time (usually this role is assigned to the state bank); fourthly, the crisis can not be avoided (Charles Kindleberger and Robert Aliber). Financial crises escalate into further economic and social ones. The oil crises can be both a cause and an effect of global financial and economic crises.

Increase of production efficiency is a number-one issue, particularly for capital-intense industries, with oil extracting industry at the head of the list. To be able to address this issue, we need solid economic research, development of novel management tools and investing mechanisms.

Of greatest importance are the matters related to efficient use of mineral resources, improved reservoir management, novel enhanced oil recovery technologies, extended reproduction of fixed assets, attracting investments for production revamping, and environmental issues.

Development of hydrocarbon fields has changed the structure of oil reserves in particular oil-and-gas basins and all over the globe.

Today, time is tough for innovative activities in Russia. In the Soviet times, all large-scale innovations were financed by the government, while in the present-day Russia the situation is somewhat different.

We possess high technology capabilities, a unique research and production potential, and highly-qualified personnel, but because of the sluggishness of economic activity this innovation potential cannot be translated into practice. In the recent years, innovation activity in Russia has sharply curtailed and the analysts are not optimistic as to its recovery in the nearest future.

Innovation activities downturn cannot be accounted for scarcity of funds alone. Particular emphasis shall be placed on improvement of innovation infrastructure (Chakhmakhchev \& Rushworth, 2010).

Oil currently accounts for $40 \%$ of the world' commercial energy mix (Fig. 1). The most part of it is used as motor fuel, about $8 \%$ to $10 \%$ as inputs for petrochemical industry for production of synthetic rubber, alcohols, polyethylene, polypropylene, and other petrochemical products (Yartiev, 2011; Ivanter \& Komkov, 2012).

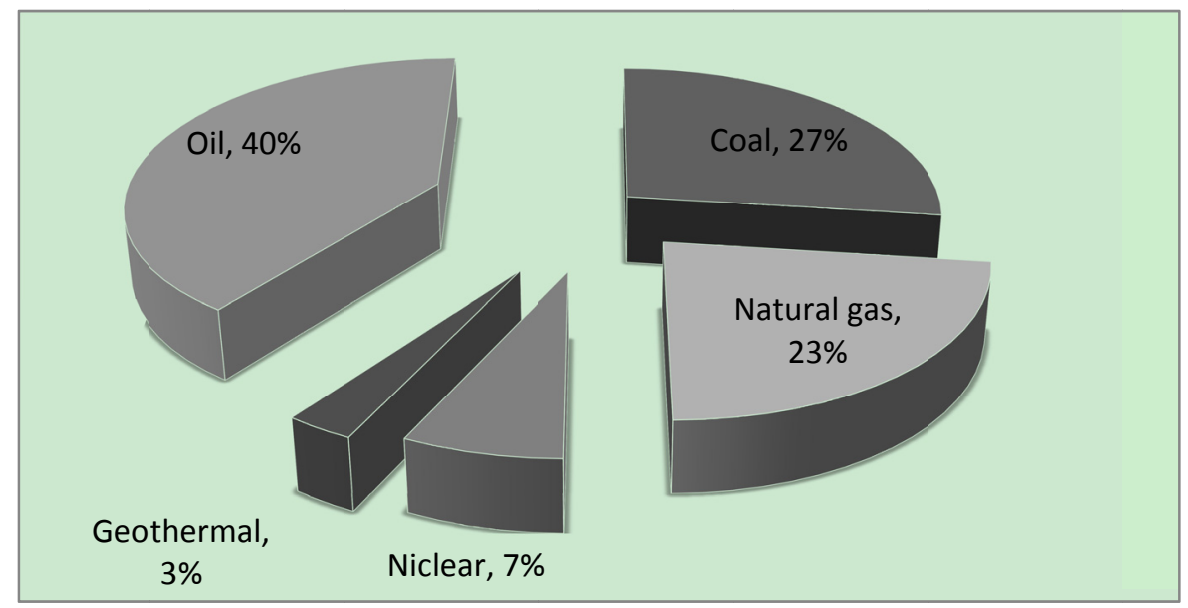

Figure 1. Global energy consumption

For how many years will these reserves suffice to meet the ever-growing energy demands? This does not depend on the production volumes alone - initial recoverable reserves play also a very important role. Table 1 presents information on proved oil reserves by top ten oil-producing countries; oil reserves of Russia are given in accordance with the high-case estimate (All About Oil, 2013, Top 10, 2012-2013).

Alan Greenspan, a famed American economist who served as Chairman of the Federal Reserve of the United States from 1987 to 2006, in his memoir The Age of Turbulence: Adventures in a New World writes that in opinion of many experts, volumes of oil supply will curtail well short of the end of the $21^{\text {st }}$ century (Greenspan, 2008). Global oil production profile in million tons per year is presented in Fig. 2 (BP, 2013; Statistical Review 2013). 
Table 1. Proved reserves by top ten countries with the largest reserves (billion of barrels)

\begin{tabular}{ccc}
\hline Country & Proved reserves as of 1 Jan 2012 & Proved reserves as of 1 Jan 2013 \\
\hline Venezuela & 296.5 & 297.6 \\
Saudi Arabia & 265.4 & 265.9 \\
Canada & 175.2 & 173.9 \\
Iran & 151.2 & 157.0 \\
Iraq & 143.1 & 150.0 \\
Kuwait & 101.5 & 101.5 \\
UAE & 97.8 & 97.8 \\
Russia & 88.2 & 87.2 \\
Libya & 47.1 & 48.0 \\
Nigeria & 37.2 & 37.2 \\
Total 10 countries & 1403.2 & 1416.1 \\
Total in the world & 1618.8 & 1547.3 \\
\hline
\end{tabular}

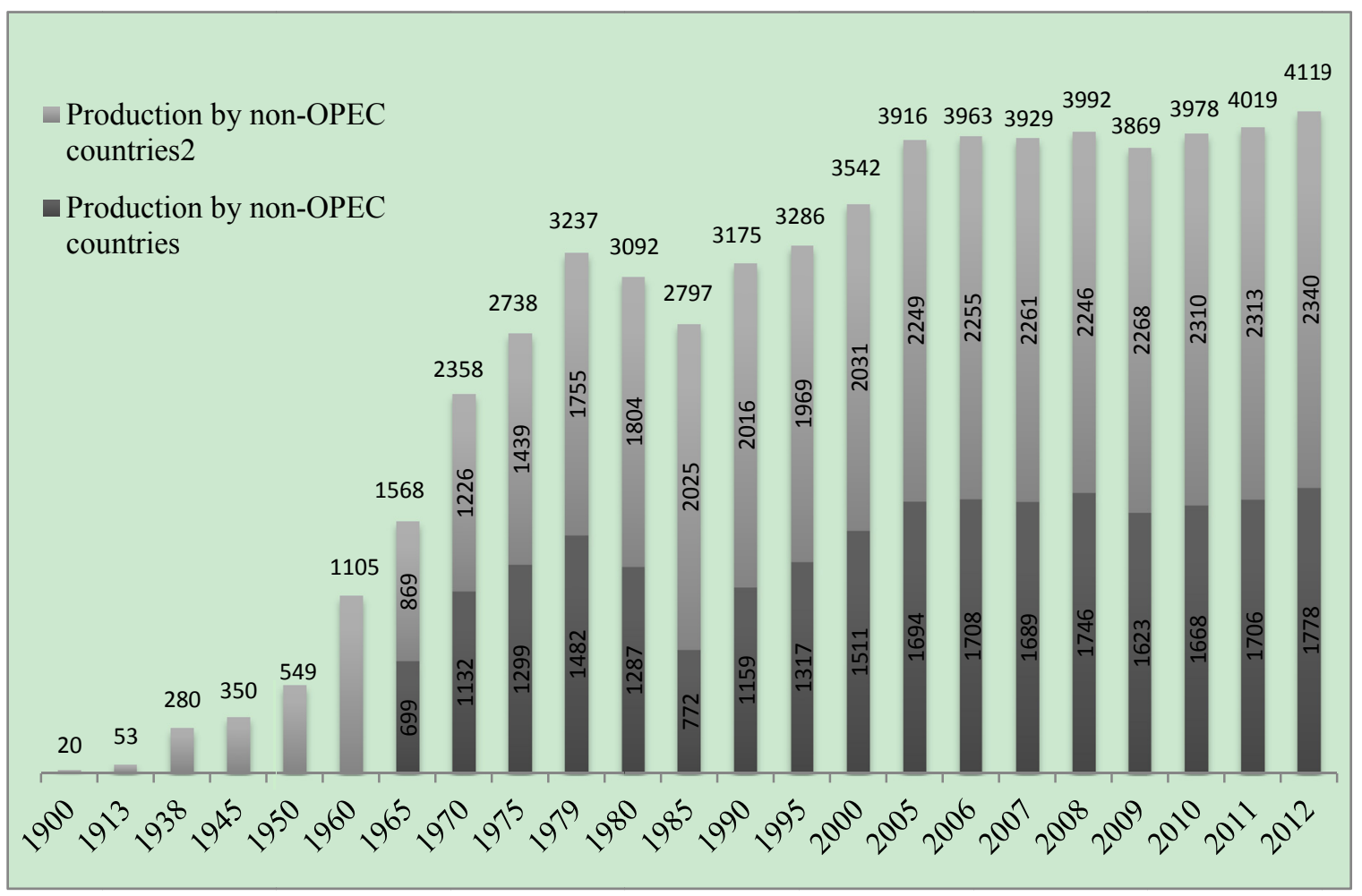

Figure 2. Global oil production profile (million tonnes per year)

\section{Materials and Methods}

According to available estimates and forecasts, oil will dominate global energy needs to 2025 .

Global conventional oil resources make, according to different estimates, from 230 to 510 billion tonnes. In 1940 s, there was no shared vision among scientists as to potential oil resources and their forecasts differed by orders of magnitude, but today spread in estimates is much less and we may infer that the resources of conventional oil contained in subsurface reservoirs have been assessed more or less accurately.

Knowing the extent of exploration of sedimentary basins throughout the world and considering the fact that potential resources tend to increase in the process of development, we may come to the conclusion that the high-case estimate of 510 billion tonnes is more realistic (BP, 2013).

By now, more than 162 billion tonnes of oil have been extracted. Proved oil reserves (not including oil sands reserves in Canada) are estimated at 175 billion tonnes. It follows that nonproved reserves of conventional light oil still have to be explored make 173 billion tonnes (34\% of initial potential resources). 
Hydrocarbons are a depleting resource, and this is not in dispute. Global oil resources are limited, and sooner or later the global society will face the reality that all existing fields have reached their peak, while new discoveries are scarce.

In the mid 60s of the XX century King Hubbert suggested the annual oil production - recoverable reserves curve for 48 southern U.S. states. The resulting bell curve shows symmetrical growth of oil production since the beginning of its commercial production in the $60 \mathrm{~s}$ of the last century with its subsequent fall, with a production peak in $1970 \mathrm{He}$ said that the decline in oil production would certainly occur, despite improvements and application of new drilling techniques. According to Hubbert, after the peak, or maximum point of production, the process of permanent and irrevocable depletion of oil wells would begin in all American oil fields (Jim Rogers). Oil supplies from the United States peaked in 1973, and by 1981 the country's oil companies have mined almost a third less oil in 48 southern states.

Jim Rogers, a finance professor in the business school at the University of Columbia, writes: "King Hubbert made a prophetic statement. Even more surprising is that he was the only person on the planet, noting that U.S. oil reserves (outside of Alaska) will be eroded. Today in the world there is a small group of new Kings Hubbert, professional geologists and energy analysts who predict that the peak of oil production in the world is not far off. Again, no one wants to listen to them "(Eric Laurent).

Everyone knows that oil and natural gas are the most important sources of energy and materials used daily by billions of people around the world. But it all began modestly enough in the XIX century, when the only product of oil refining was kerosene and gasoline fraction was burned in pits.

The first oil company was founded in the United States under the name Pennsilvania Rock Oil. The first well was drilled in America in 1859. The first refinery was opened in 1865 in New York.

The beginning of rapid growth of the oil industry is largely due to the names of people who had no direct relation to it. First of all these are Nicholas Otto, Gottlieb Daimler and Wilhelm Maybach as well as Karl Benz, who created the first internal combustion engines. Wright brothers first plane, initiating aviation and Henry's Ford conveyor created a constant demand for gasoline. With the development of the aviation and automotive industry beginning of most of the oil was processed into gasoline.

The increase in oil production and refining lasted nearly for the whole XX century. The exception was the period between 1974 and 1985, when the world oil crisis prevailed. Oil shortages caused major consuming countries to introduce energy saving policy. Citizens of the United States, where the peak of oil production occurred in 1971, had to choose more fuel-efficient vehicles. However, after the crisis, the growth of oil production continued. Over the years of crisis rich countries have become accustomed to save, but developing countries needed more oil year after year.

Usually, once $40 \%-60 \%$ of OOIP have been produced, oil production declines by $5 \%-15 \%$ per year and to maintain the attained oil production level, operators have to bring oil new fields into development. Thereat, operators exert every effort to decrease oil production decline in fields under development. These include EOR and well stimulation treatments, novel drilling technologies, etc. To maintain a stable oil production is, thus, associated with much more expenses and effort than to bring new fields in production.

In the coming decades global oil demand will continue to grow to reach 5.96 billion tonnes in 2020 , according to analysts' forecasts.

One of the basic issues facing the global society is to ensure that oil resources will be available to meet these growing demands.

\section{Results}

The world's explored and estimated global resources of conventional oil will be enough to meet demand for the next 46 years, at current production rates. However, in practice, the situation is a bit more optimistic than this. It has been known that forecast resources increase as we acquire more knowledge about sedimentary basins. Figure 3 shows global structure of oil reserves and potential for new discoveries (Yartiev, 2011; World energy consumption, 2012).

More than $50 \%$ of 1300 sedimentary basins discovered in the world show promise for search for hydrocarbons. So far, detailed survey has been carried out only in half of these promising basins. Offshore zones, as well as continental margins, offer great opportunities. It is believed that "extreme" zones may contain large reserves of untapped oil and gas: one-fifth of undiscovered light oil reserves (non-OPEC) are contained in deep sea, one-third - in the Arctic regions. 


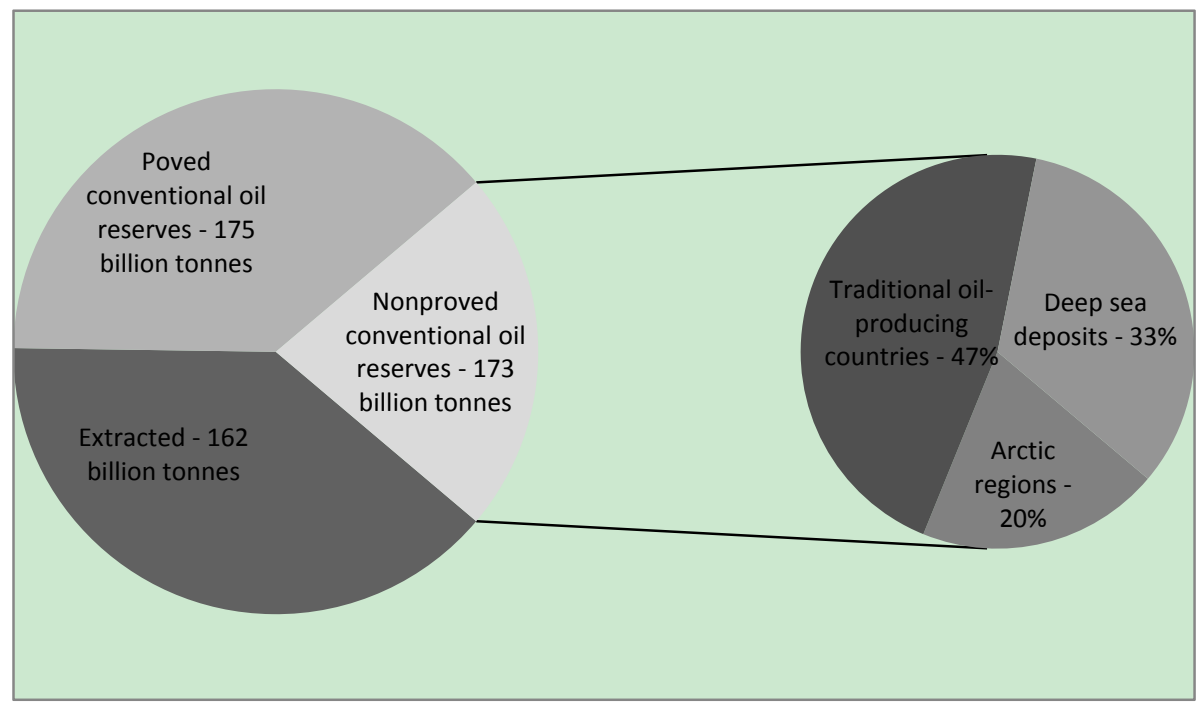

Figure 3. Global structure of reserves and potential for new discoveries

\section{Discussion}

Vast natural resources have always helped Russia to keep afloat in the hardest times of our history. Today, natural resources are Russia's comparative advantage, oil and gas are the engine of the Russian economy. Russia's commodity exports, including oil and natural gas, account for a significant share of the budget revenues.

Plans for economic development of Russia include further development of production and export capabilities and enhancing Russia's status as an important world energy power. This ambitious goal is underpinned by a strong raw materials base and a developed industrial potential.

Oil and gas fields in Russia represent a wide vertical range, which can be divided into four large areas (reservoir) of oil and gas reserves, such as from the Precambrian to Paleozoic, upper Paleozoic, Mesozoic and Cenozoic. Based on the statistics the most famous and largest oil reserves are in areas such as the East Siberian gas and oil pool, deposits of oil in the formations from the Precambrian to Paleozoic, deposits in the upper Paleozoic strata are mainly distributed in the Volga-Ural Basin and Timan-Pechora Basin. Oil reserves in formations of Mezozzoyya are widespread mainly in the West Siberian Plain and in the southeastern part of the Barents Sea, such stocks as well can be found in the North Caucasus and in the East Siberian oil and gas basins. Kaynazoyskie oil reserves are mainly widespread in the north of Sakhalin oil and gas basin of the Far East of Russia. Based on the analysis of the oil and its major stocks, we believe that the key point is the basic evaluation unit to measure the inferred resources using the exploration of new oil and gas fields. The results show that in Russia today there are still a large number of unused and unknown oil and gas fields located in the East Siberian region and the eastern Barents Sea.

Despite the high cost of drilling and significant remoteness of the Arctic region and emerging technical problems at low temperatures, there is now a great attention to energy resources in the Arctic. In 1920 Exxon Mobil discovered most Sereni field. In Russia, geological investigations in the Barents and Kara Seas began in the 19th century. More systematic studies have been carried out in the period from 1920 to 1930 in the New Earth. However, deep drilling near Franz Josef Land began only in the late 1980s. (Piskare \& Shkatov, 2012)

In the last decade, there has been increased interest to the region by both politicians and businesses. This is due to global warming and the subsequent melting of Arctic ice. Even those countries that are geographically far away from this area, namely, Singapore, China, South Korea, Italy and India have shown an interest to the energy resources of Arctic. This is due to the following circumstances: firstly, an opportunity to more in-depth study of energy resources, and secondly, the use of the Northern Sea Route considerably reduces the cost of exploration and production of minerals. As a consequence, these countries have submitted a request and recently have received observer status in the Arctic Council. In the last decade such countries as the USA, Canada, Denmark, Norway and Russia began issuing licenses for mineral exploration in the Arctic region.

Russia has major projects planned for the study of the Shtokman field in the Barents Sea, together with Total and Statoil, as well as on the Yamal Peninsula. 
All this activity may indicate that the Arctic is becoming urgent for the study area. However, many challenges remain, such as the high cost of drilling. Political and economic risks of oil production will not allow to ensure the current oil production forecast resources of hydrocarbons in the short term.

Russia's involvement in international division of labor as a leading energy resources exporter sets the priority for a foreign-policy course towards development of economic ties with other countries and international organizations, OPEC in the first place. Shrewd foreign economic policy is also a guarantee of Russia's social and economic wellbeing.

As projected by "2020 Development Strategy" and "2030 Development Strategy", by the end of the current decade, annual oil production will be raised to 520 million tonnes, natural gas - to $680-730$ billion cubic m, production of motor fuel - to 115-135 million tonnes (Energy Strategy of Russia).

To achieve these goals, Russian oil and gas sector has to tackle a number of challenges, including:

- Substandard infrastructure

- Sharp deterioration of raw material base, including high extent of hydrocarbons reserves depletion

- Deterioration of reserves structure, increase of the share of hard-to-recover reserves

- Disparities between domestic and export prices

- Heavy depreciation of fixed assets

- Insufficient capital investments

- Tough taxation policy

The "2030 Development Strategy" places emphasis on development of the Western Siberia and continental shelf regions, while traditional oil-producing regions are practically ignored.

Doubtless, the regions with the yet untapped reserves have to be developed, but it is also true that they need huge investments, which might be a real challenge, while, under certain conditions, old oil regions with the developed infrastructure are able to contribute significantly to sustained oil production.

To realize the "2030 Development Strategy" objectives, an estimated total cost of USD230-240 billion is needed, which in terms of 1 tonne increase of oil production is 11 times higher than in Persian Gulf countries and 7 times higher than in OPEC (Top 10 Oil Producing Countries in the World 2013-2014).

This is accounted for by remoteness, complex environmental conditions, and nascent infrastructure. Actually, the "2020 Development Strategy" objectives will be achieved at the expense of traditional oil producing regions with the yet high hydrocarbon potential. Figure 4 presents oil production profile in Russia (BP, 2013).

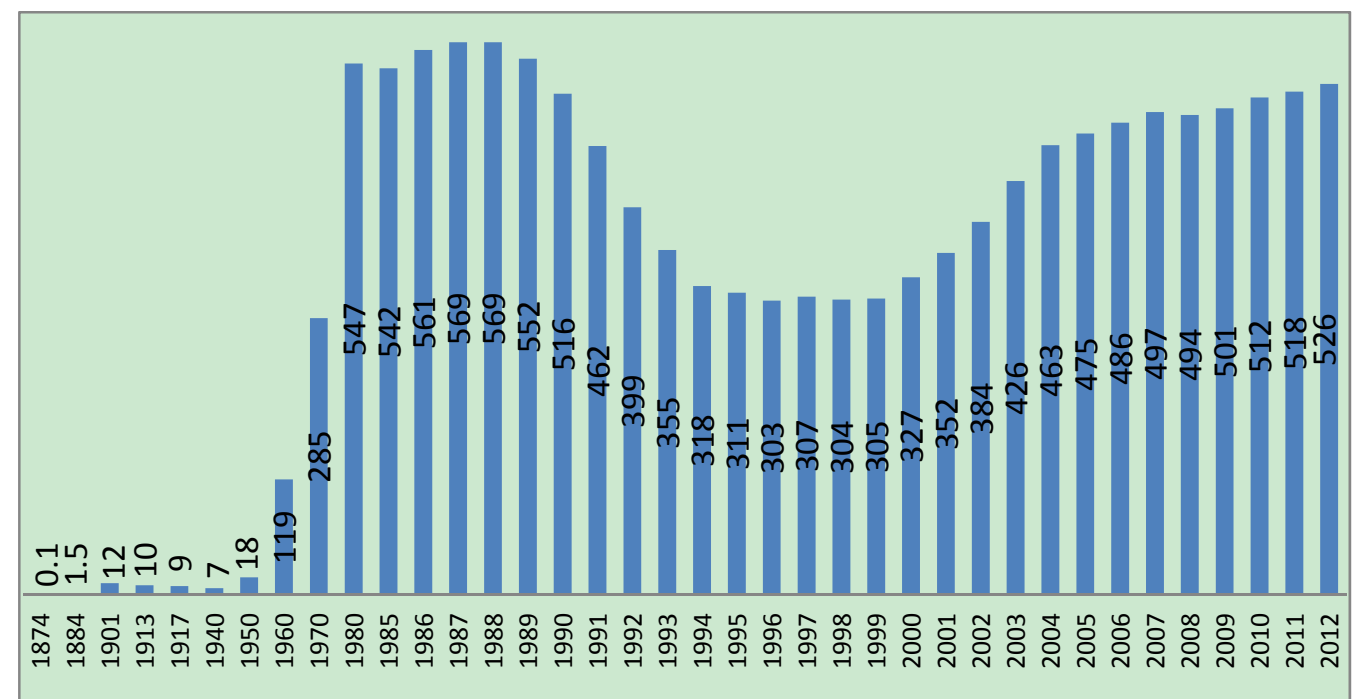

Figure 4. Oil production profile in Russia (million tonnes) 


\section{Conclusion}

New technological solutions imply extensive use of the latest technologies. This is particularly true for extraction of heavy oils.

So far, the problem of high-performance and effective development of hard-to-recover and heavy oil reserves has not received sufficient attention in Russia. Given in-place and, in particular, estimated recoverable heavy oil reserves, wide range of in-situ conditions and reservoir properties, and a very challenging production process, R\&D including field-scale pilot projects to test new recovery, transportation, and processing technologies come to the fore.

Innovation policy in fuel and energy sector shall pursue extensive application of resource-efficient technologies, mitigation of environmental impact, and enhanced operational reliability of production, transportation, and energy resources' storage systems.

In today's globalizing world, the advanced countries aim their efforts at building energy-efficient societies, which cannot be done without changing mindsets, development of game-changing technologies, and creating new social institutions. Resource efficiency is seen as an integral part of Russia's sustainable development.

\section{References}

All About Oil (Russian-language). Retrieved from http://vseonefti.ru/

All About Oil. Retrieved from http://motorcycleinfo.calsci.com/Oils1.html

BP Statistical Review of World Energy. (2013, June). Retrieved from http://www.bp.com/content/dam/bpcountry/es_es/statistical_review_of_world_energy_2013.pdf

Chakhmakhchev A., \& Rushworth, P. (2010). Global Overview of Recent Exploration Investment in Deepwater New Discoveries, Plays and Exploration Potential. Retrieved December 17, 2010, from http://www.search anddiscovery.com/pdfz/documents/2010/40656chakhmakhchev/ndx_chakhmakhchev.pdf.html

Energy Strategy of Russia for the Period till 2020. Russian Government Executive Order as of 28 Aug 2003. No.1234-p.

Energy Strategy of Russia for the Period till 2030. Russian Government Executive Order as of 13 Nov 2009. No.1715-p.

Greenspan, A. (2008). The Age of Turbulence: Adventures in a New World (p. 563). EUA: Penguin Press.

Ivanter V. V., \& Komkov N. I. (2012). Basic Principles of the Concept of Innovation Industrial Development of Russia. Problemy Prognozirovaniya, 5, 3-12.

Kindleberger, Ch., Aliber, R., Manias, P., \& Crashes. (2010). A History of Financial Crises (p. 544). Translated from English by 'Lider. Saint-Petersburg.

Laurent, E. (2008). Oil: Lies, secrets, fraud (p. 432). Translated from French by T. Zhdanova. Moscow: Stolitsa-Print.

Muslimov, R. Kh. (2012). Oil production: The Past, the Present and the Future (p. 664). Kazan: FEN, Academy of Sciences, RT.

Piskare, A., \& Shkatov, M. (2012). Energy Potential of the Russian Arctic Seas. Oxford: Elsevier.

Rogers, J. (2008). Hot Commodities: How Anyone Can Invest Profitably in the World's Best Market (p. 256). Translated from English by Matskovskaya. Moscow: Olymp-Business.

Statistical Review of World Energy 2013 (in Russian). Retrieved from http://vseonefti.ru/upstream/

Top 10 Oil Producing Countries in the World 2013-2014. Retrieved from http://www.thecountriesof.com/ top-10-oil-producing-countries-in-the-world-2013-2014/\#sthash.TzlzYCaZ.dpuf.

World energy consumption (2012, June). Retrieved from http://en.wikipedia.org/wiki/World_energy_ consumption

Yartiev, A. F. (2011a). Improvement of Flow Method and Energy Costs Accounting (p. 128). LAP LAMBERT Academic Publishing.

Yartiev, A. F. (2011b). Oil Trends in Russia. Problemy ekonomiki i upravleniya neftegazovym kompleksom, 3 , $22-25$.

Yartiev, A. F. (2012). Estimate of Design solutions for Development of Oil Fields (p. 224). LAP LAMBERT 
Academic Publishing.

Yergin. (1999). The Epic Quest for Oil, Money, and Power (p. 968). Translated from English. Moscow: DeNovo.

\section{Copyrights}

Copyright for this article is retained by the author(s), with first publication rights granted to the journal.

This is an open-access article distributed under the terms and conditions of the Creative Commons Attribution license (http://creativecommons.org/licenses/by/3.0/). 